following are defined: determination of types and forms of choral festivals-competitions.

Key words: genesis, festivals, competitions, performance, choral creative work.

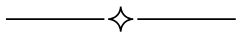

УДК 78.071.1/786.2

\author{
E. Хиль
}

\title{
ПЕРВЫЙ ФОРТЕПИАННЫЙ КОНЦЕРТ С. ПРОКОФЬЕВА КАК ПРЕДМЕТ СТИЛЕВОЙ МНОЖЕСТВЕННОСТИ ИСПОЛНИТЕЛЬСКИХ ИНТЕРПРЕТАЦИЙ
}

Статья посвящена характеристике Первого фортепианного концерта С. Прокофьева в направленности на актуальное в современности интонационное решение. В центре анализа указанного сочинения С. Прокофьева - выявление стилевых составляющих композиции, которая оказалась в числе ранних сочинений репрезентантом авторского композиторского стиля и отражением стилевых преобразований мирового искусства 1910-х годов, которые образуют стилевую палитру интерпретационных поисков сегодняшнего дня.

Ключевые слова: концерт как жанр, актуальная интонация, исполнение музыки, фортепианная выразительность звучания, стиль в музыке.

Актуальность темы работы определена неисчерпаемостью гения С. Прокофьева для новых исполнительских прочтений, источником которых выступает стилевая симультанность сочинений великого русского композитора, жизненными обстоятельствами и культурными истоками связанного с судьбой музыкальной Украины, неоднократно в своем творчестве использовавшего украинские образытемы. Обновление исполнительских установок согласно исторически меняющимся вкусам публики, пристрастиями которой четко управляет мистический по названию и совершенно реально-обыденный по психологии артистической деятельности - «дух эпохи», порождающий явление, терминологически обозначенное как «актуальное интонирование» [5].

Целью данной работы выступает анализ Первого фортепианного концерта С. Прокофьева в аспекте стилевых составляющих произведения, оказавшегося в числе ранних сочинений репрезентантом

(C) Хиль Е., 2014 
авторского композиторского стиля и отражением стилевых преобразований мирового искусства 1910-х годов, что составляет стилевую палитру интерпретационных поисков сегодняшнего дня. Конкретные задачи - выделение стилевых тенденций, объективно обнаружившихся в 1910-е годы и получивших специальное развитие в эпоху постмодерна 2000-х годов, а также анализ Концерта Прокофьева в свете представлений об означенной стилевой симультанности и с выходом на исполнительскую концепцию, реализующую «актуальное интонирование» произведения в 2010-е.

Методологической основой произведения выступает интонационный сравнительно-стилевой анализ (компаративный метод в музыкознании), сформированный Б. Асафьевым [3] и его последователями [10; 11], в том числе в Украине [5; 8]. Существенным является герменевтический ракурс, завещанный работами Г. Кречмара [7] и Б. Яворского [4], а также культурологический срез [8], определяющий упор на исполнительские основания музыкального профессионального мышления. Научная новизна работы определена оригинальностью теоретического подхода к произведению, составляющего одно из наиболее востребованных сочинений композитора в современном пианистическом репертуаре. Практическая ценность обусловлена потребностями исполнительского творчества тем, что материалы исследования могут быть использованы на занятиях в спецклассе фортепиано, а также в курсах теории и истории музыкального исполнительства в высшей и средней музыкальной школе.

Первый концерт С. Прокофьева для фортепиано с оркестром Des-dur был создан автором в 1911-1912 годах, отмеченных проявлением в художественной сфере качества стилевого «авангарда», воспринимавшегося современниками в активной соотнесенности с модерном конца XIX - начала XX века и академизировавшимися направлениями предыдущих эпох. Сама тональность Des-dur, гимнический фортепианно-оркестровый зачин композиции четко создавал аллюзии к общему тонусу звучания Первого фортепианного концерта П. Чайковского (написанного в b-moll, однако данного в «омажоренном свечении» Des-dur'ной опорности на VI ступени в исходной и основной теме произведения). Поэмная одночастная структура и обилие крупной техники ориентировали на связь с Концертами Ф. Листа и пианизмом А. Рубинштейна. А начальная ритмоформула псалмодирующей фигуры (в темпе Allegro brioso) явно указывала на 
инверсионно преобразованную кантовую последовательность глинкинского «Славься».

Однако указанные «отсылки к традиции» Первого концерта юного композитора, с этим произведением утверждавшего и свою исполнительскую пианистическую позицию «металлической» игры, не были замечены критиками (как понимаем, публика была более адекватна в принятии идеи произведения). Попытаемся осознать тот раздражающий «молодежный» тонус Первого концерта Прокофьева, который так очевидно заслонял в восприятии многих современников традиционные средства выражения.

Одним из самых откровенно ругательных отзывов было заявление Н. Бернштейна в том духе, что это «безумное» сочинение, к которому применим эпитет «музыкальная грязь» (цит. по: [11, с. 76]). Общий взгляд на интервалику аккордовой вертикали этого Концерта убеждает в умеренности тех построений, которые предлагал молодой автор на фоне музыкальных экзотизмов Н. Римского-Корсакова, К. Дебюсси, тем более А. Скрябина. На первом месте в ряду обвинений в «окончательном искривлянии» (см.у Л. Сабанеева [11, с. 76]) стоит - «энергически ритмованная жесткость и грубость», «примитивная какофоничность» и т. д. То есть речь идет о недопустимом, с точки зрения критиков, опрощении ритмической стороны изложения, достигшей апогея полиритмических напластований у наследника шопеновского ритмо-виртуозничества - А. Скрябина (преданным адептом последнего был Л. Сабанеев, наиболее авторитетный из хулителей раннего Прокофьева).

А в защиту юного гения В. Каратыгин выдвигал следующее: «Сколько в его концерте новых и свежих гармоний, так четки, сочны и оригинальны здесь мелодии, так упруга везде ритмика (здесь и дальше курсив наш. $-E$. X.), а главное - все время ключом бьет жизнь, сверкает солнце живой фантазии» [12, с. 4]. Из сказанного напрашивается один вывод: раздражающе либо покоряюще новым для современников было - ритмоощущение и общий «солнечно-ясный» нерефлексирующий тонус выражения Прокофьева.

Первый концерт С. Прокофьева сочинен был в 1911 году, который стал знаменательной вехой в его творческой биографии - см. тезис: «Период до 1911 года в композиторской деятельности Прокофьева был периодом первоначального набирания сил»; и далее - «...3наменательная веха в жизни Прокофьева: в этом году он впервые начал печататься, впервые выступил в открытом симфоническом концер- 
те и... написал первое вполне самостоятельное крупное произведение...» $[11$, с. 64,66$]$.

Данные сугубо личностные стечения обстоятельств биографии Прокофьева были категорически усилены этапностью 1911 года в мировом музыкальном раскладе. В ряду Первого фортепианного концерта Прокофьева стоят произведения, открывшие стилистику $\mathrm{XX}$ века в разнообразии и противостоянии направлений. В том числе это: «Петрушка» И. Стравинского, «Лунный Пьеро», «Ожидание», книга «Учение о гармонии» А. Шенберга, «Синяя Борода» и «Allegro barbaro» Б. Бартока, «Ноктюрн» Н. Лысенко, «Кавалер роз» Р. Штрауса, наконец, это столь эпохальное событие как создание объединения «Русский балет Сергея Дягилева» и др., определивший для всего мира стиль русской музыки в XX веке.

В варианте оперных сочинений Шенберга и Бартока, созданных совершенно независимо друг от друга, поражает точное «попадание» обоих в концепцию «сжатой» оперы (моноопера, опера-диалог), заявляющей концепцию мироздания, аналогично - пассионная структура на теме Креста в «скерцо» в «Allegro barbaro» Бартока.

«Ноктюрн» Лысенко - также «сжатая» опера, в которой композитор полностью отказывается от драматических акцентов предыдущих оперных сочинений - и это качество выражения роднит с «Кавалером роз» Р. Штрауса, в котором композитор открывает новый для него стилевой пласт - неоклассический, причем умеренно-неоклассический, что коренным образом противостоит его предэкспрессинистским образам «Саломеи» и «Электры» 1905-1907 гг. «Петрушка» Стравинского и «Лунный Пьеро» Шенберга - иное: это разрыв с импрессионистско-символистским строем сочинений предыдущих годов в пользу фовистских-примитивистских комплексов.

Заметим, данный смысловой поворот впоследствии непосредственно ни у них, ни у других авторов не повторялись: «Лунный Пьеро» стилистически уникален в наследии его творца, тем более по отношению к другим авторам - подражания стилистике этого опуса не найдем ни у одного из композиторов-профессионалов (разве что это «песенки» А. Вертинского, вернее, совокупный его сценический-артистический облик...). Уникальность и энергию «поворотного» действия «против течения» (см. название книги балетмейстера М. Фокина) относительно «Русского балета С. Дягилева» или «Учения о гармонии» Шенберга, доказывать не приходится. 
Как это подчеркнуто в работе Е. Марковой [8], все названные яркие сочинения, отмеченные 1911 годом создания, представляют четко данный поворот у их авторов - «к новым берегам», $\kappa$ бескомпромиссно избранным разрывом с наработанными ранее стилистически-видовыми показателями, но также составляющих «стиль по пункту исключения» в личностно-авторском стилевом континууме и эмблематичном по отношению к авторскому кредо в целом. И, наверное, «странная камерность» звучания «Лунного Пьеро» Шенберга и символистская салонность «Ноктюрна» Лысенко наиболее полно обозначают феномен открытий 1911 года (ибо художественные открытия 1907-1908, 1912-1913, 1917 и других лет - имеют принципиально другие смысловые характеристики).

Так наполняется конкретикой общности в принципиально разном то, что связывается на сегодня с представлением об «эпохальном» стиле в исторической науке и в истории искусства (см. «интонационный словарь эпохи» Б. Асафьева [3]), который характеризует тот «исторический индетерминизм» эпохальных территориально-региональных взаимодействий в гуманитарном знании и который имеет параллель к физическому индетерминизму микромира (см. у Э. фон Нейманна по поводу квантового индетерминизма как проявления «поведения» природы, в котором «не всегда» обнаруживается действие закона достаточного основания [1, с. 189].

В 1952 году была опубликована работа К. Юнга совместно с В. Паули «Синхронистичность как принцип акаузальных взаимосвязей» [1, с. 190-191]. Как констатируется в книге Д. Арабаджи, в работе К. Юнга «рассматриваются феномены, которые нельзя постичь с помощью принципа каузальности (причинности): речь идет о неких связанных по смыслу совпадениях» [1, с. 191]. То, что Юнг называет «новой связью», есть иное, чем «причинная связь». «Новая связь» для Юнга - «смысловая связь», потому что: «...единственной заметной и доказуемой связью между ними (событиями) является общность смысла или эквивалентность» [1, с. 182].

Как видим, переломность биографии Прокофьева в 1911 - не случайна: это выход на новые, авторски осознанные рубежи творчества, совпадающий с выдвижением нового этапа в развитии русской музыки, европейского художественного мира в целом. И отмеченные современниками ритмические примитивизации, отказ от трагической рефлексии и психологизма, столь по-разному оцененные слушателями Первого фортепианного концерта Прокофьева, составили новое 
качество самовыражения, острота восприятия которого невозможна во второй половине XX века и в 2000-е годы. Кроме того, Прокофьев в своем Первом концерте определил концепцию жанра данного произведения как некоторой альтернативы «ансамбля солирующего инструмента с оркестром» и «превосходность» партии-соло в единстве с «придаточностью» партии оркестра [12, с. 4].

Такой «альтернативный» подход Прокофьева совершенно игнорирует классику постбетховенского листианского симфонизированного «соревновательного» (то есть театрально-диалогизированного) концерта - в пользу разновидностей монологичности облигатной концертности доклассического склада. Л. Раабен констатирует применительно к фортепианному стилю Прокофьева в целом и в отношении к анализируемому Первому концерту - «токкатность», множественность «штрихов non legato» и «острых стаккатных звучаний», при - «изяществе фактуры», «изяществе и прозрачности тембров (особенно в лирике...)» [12, с. 3]. Сказанное свидетельствует о клавиризации фортепианного стиля Прокофьева, явно избегающего оркестровых контрастов кантилены-соло и туттиевых звучаний листовского-рубинштейновского пианизма. Господствующий тип звучания - моторика, в том числе изящная, ломкая-хрупкая, как это имеет место в темах главной, побочной партий, в эпизоде Andante и др.

Указанная установка на моторику как постоянный компонент тематических наполнений композиции содержит связь с просимволистским пластом музыкального выражения, что косвенно фиксировалось в критическом очерке в Петербургском листке от 5 августа 1912 г., в котором фиксировались четыре исторических этапа становления русской названы школы - от М. Глинки до А. Скрябина и С. Прокофьева [11, с. 76]. Причем представляемые на каждом из «этапов» пары имен (Глинка - Рубинштейн, Чайковский - Римский-Корсаков, Глазунов - Аренский, Скрябин - Прокофьев) не образовывали стилистических антитез (особость Даргомыжского и Мусоргского «выпали» из стилистических преобразований школы), демонстрируя скорее дополнительность, чем альтернативы.

Так, декларативно-моторной является тема вступления, трижды звучащая в Концерте, придающая его строению рондальные черты, ритуализирующие эффектом perpetum mobile типологию сонатных тематических смен, которые менее всего обнаруживают антитетичность, монологизируя изложение музыки Концерта. Псалмодическая 
фигура и линия восхождения, составляющие базисные риторически высокие знаки темы-рефрена, темы вступления Концерта, обнаруживаются и в каденции (ц. 3, Рoco piu mosso) в виде преимущественно «линейных» фигур, и в главной партии (ц. 7, Тетро primo) как обыгрывание в основном псалмодирующего, педально речитирующего построения, аналогично, в побочной партии (ц. 12, Meno mosso).

Темпово-фактурные расцвечивания тем Концерта исключают их противопоставление: во всех этих темах главным «нервом» выражения выступает юная энергийность, различающаяся по степени проявления одной и той же идеи-образа: молодая радостная Устремленность к Высокому. Такого рода бесконфликтность решения сонатной схемы целого обнажает в поэмной структуре одночастного Концерта показатели вариации-сюиты, что соответствует барочному генезису концертной формы (ср. с органным Концертом d-moll А. Вивальди, напр.). Эта установка на гимническую ясность звучания, оттеняемого таинственными контурами музыки шествия в побочной партии, в музыке которой И. Нестьев улавливал признаки «странной сказочности» [11, с. 75], соотносима со строем концертного жанра в сочинениях П. Чайковского и С. Рахманинова, откровенно приближенных к духовным истокам указанной жанровой типологии и обнаружившихся в демонстративном противостоянии трагико-драматическим искусам их оперно-симфонических сочинений.

«Странная сказочность» побочной моторно расцвечена в зеркальной репризе (от ц. 31, Росо piu sostenuto), сообщающей набирание «массы движения» в ритмических остинато контрапунктирующих к основным темам-образам линий. Реприза Концерта замечательно демонстрирует ту оригинальную контрастную полифонию фактурных решений (соединение фактурной идеи «тарантельности» главной партии со «странным маршем» основной темы побочной - от ц. 31), которая составляет отличительное качество мышления Прокофьева в его породненности с аналогичной фактурной установкой М. Глинки, а этого последнего с французскими истоками моцартианского мышления. Ибо при всей «густоте» октавных «лент» в фактуре Концерта последняя демонстрирует явное преобладание «двупластовости» изложения, являя укрупненное-утяжеленное изложение клавирно-клавесинного двухголосия музыки старых мастеров франко-британской школы, - именно к данному типу выражения направлено было обучение у Н. Черепнина, мирискуснические симпатии которого питались откровенным моцартианством. 
Из сказанного напрашиваются следуюшие выводы относительно исполнительских прочтений Первого фортепианного концерта С. Прокофьева, обнаружившего в постсимволистской художественной концепции очевидные аналогии к барочным формам протопоэмного типа:

1) выделение ритмической энергии «стального» perpetum mobile, примитивистская искренность которого отвращала либо восхищала при первых слушаниях сочинения в далекие 1910-е годы;

2) улавливание преемственности по отношению к игровой моторике импрессионистских-символистских полотен, апеллировавших к «симуляции детскости» клавирного рококо XVIII века;

3) подчеркивание барочной гимнической истовости звучания, идущей от глубин бесконфликтного тематизма и надиндивидуальной лирики ранних концертов;

4) нахождение точек соприкосновения с академическим романтическим тонусом изложения, питавшего Прокофьева при посредничестве А. Глазунова, влияние которого на юного композитора несомненно имело место.

Известные исполнители произведений С. Прокофьева С. Рихтер, М. Аргерих, Ланг Ланг представляют разные грани стилевых выходов, из которых первый, С. Рихтер, явно проецирует опыт своего исполнительского бахианства и бетховенианства, создавая тип монументально-торжественного звучания, соотносимого с идеей искусства барокко. М. Аргерих, как никто другой, охватывает связь с фигуративностью моцартианства, запрограммированного, хотя и не претендующего на первоплановый ряд, композиторским текстом. Несомненно, в исполнении Ланг Ланга наиболее узнаваем молодежно-эпатирующий принцип звучания Концерта, тогда как большинство современных озвучиваний данного произведения, в том числе в учебной консерваторской практике исполнения Прокофьева, направлены к опоре на академическую романтизацию стиля сочинения.

С учетом неосимволистской [9] волны современного поставангарда и свойственной этому последнему стилевой настройки на облегченно-«полетный» тип игры, интерпретации М. Аргерих и Ланг Ланга претендуют на привилегии в актуально-интонационных предпочтениях, хотя объективные художественные достоинства исполнения Рихтера, бывшего доверенным лицом композитора в преподнесении на публику его фортепианных сочинений, обладает нетленными достоинствами. 


\section{СПИСОК ЛИТЕРАТУРЫ}

1. Арабаджи Д. Между сакральным и профанным: [Сб. статей] / Д. Арабаджи. - Одесса: Друк, 2009. - 224 с.: ил.

2. Арабаджи Д. Очерки Христианского символизма/ Д. Арабаджи. Одесса: Друк, 2008. - 548 с.: ил.

3. Асафьев Б. Музыкальная форма как процесс / Б. Асафьев. - М.; Л.: Музыка, 1971. - 379 c.

4. Берченко Р. В поисках утраченного смысла. Болеслав Яворский о «Хорошо темперированном клавире» / Р. Берченко. - М.: Классика-XXI, 2005. - $372 \mathrm{c}$.

5. Вєркіна Т. Актуальне інтонування як виконавська проблема: Автореф. дис. ... канд. мист.: 17.00.03 / Т. Вєркіна. - Одеса, 2008. - 16 с.

6. Давидов М. А. Виконавське музикознавство як феномен української наукової традиції / М. А. Давидов // Виконавське музикознавство: Енциклопедичний довідник. - Луцьк: Волинська обласна друкарня, 2010. C. 4-6.

7. Кречмар Г. История оперы / Г. Кречмар. - Л.: Academia, 1925. - 406 с.

8. Маркова Е. И. А. Котляревский в контексте творческих предпочтений поколения 1950-х - 1960-х гг. / Е. Маркова // Трансформація освіти і культура: традиції та сучасність: Зб.матер. Міжнар. науково-творчої конференції. Київ, 2-3 травня, 2012 р. - К.: НАКККіМ, 2012. - С. 113-126.

9. Маркова Е. Неоевропоцентризм и неосимволизм начала XXI века / Е. Маркова // В. Холопова, Л. Канарис, Е. Маркова, С. Таранец. Неоевропоцентризм: музыкальная культура на рубеже столетий. Книга 1. - Одесса: Астропринт, 2006. - С. 76-128.

10. Медушевский В. Онтологические основы интерпретации музыки / B. Медушавский // Интерпретация музыкального произведения в контексте культуры: [Сб. ст]. - М., 1984. - Вып. 129. - С. 5-11.

11. Нестьев И. Жизнь Сергея Прокофьева / И. Нестьев. - М.: Сов. композитор, 1973. - $662 \mathrm{c.}$

12. Прокофьев С. Концерт № 1 для фортепиано с оркестром. Переложение для двух фортепиано / Вступ. статья Л. Раабен: Сергей Прокофьев. - М.: Музгиз, 1962. - $52 \mathrm{c}$.

13. Юнг К. Синхронистичность: акаузальный объединяющий принцип // К. Г. Юнг Синхронистичность: Сборник. - М.: Рефл-бук; К.: Ваклер, 1997. $-179 \mathrm{c}$.

Хіль О. Периий фортепіанний концерт С. Прокоф'єва як предмет стильової множинності виконавських інтерпретацій. Стаття присвячена характеристиці Першого фортепіанного концерту С. Прокоф'єва в спрямованості на актуальне в сучасності інтонаційне рішення. В центрі аналізу вказаного твору С. Прокоф'єва - виявлення стильових складових композиції, що представляє ранні твори в репрезентації авторського композиторського 
стилю і у відображенні стильових перетворень світового мистецтва 1910-х років, які складають стильову палітру інтерпретаційних пошуків сьогоднішнього дня.

Ключові слова: концерт як жанр, актуальна інтонація, виконання музики, фортепіанна виразність звучання, стиль в музиці.

Khil E. S. Prokofiev's first piano concert as subject of style plurality of performing interpretations. The article is devoted to the attribute of the First piano concert by S. Prokofiev that trends towards an intonational decision actual in the present time. In the center of our analysis of S. Prokofiev's specified work stands the identification of style components of this composition that turned out to be a representative of the author's composer style among his early creations and a reflection of stylistic transformations of the world art of 1910th years that are forming the style palette of interpretative searches of today.

Key words: concert as a genre, actual intonation, music performance, piano expressiveness of sounding, style in music.

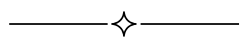

УДК 78.05/787.1

\section{К. Швець}

\section{СКРИПКОВЕ ВИКОНАВСЬКЕ МИСТЕЦТВО ЯК ВАЖЛИВА СКЛАДОВА СУЧАСНОЇ МАСОВОЇ КУЛЬТУРИ}

Стаття присвячена вивченню явища масової музичної культури, яка розглянута як культура більшості, культура побуту, розваг та інформації, положення якої є провідним у сучасному суспільстві. Зміст масової культури обумовлений щоденними подіями, прагненнями та потребами, з яких складається життєвий уклад більшості населення (т. зв. мейнстрима). Масова музична культура є найбільш розповсюдженою формою розваг, інформації та несе просвітницьку функцію у суспільстві, вражає численними проявами.

Ключові слова: культура, масова культура, мейнстрим, сучасне скрипкове виконавство.

Актуальність обраної тематики пояснюється тим, що масова культура займає значне місце у сучасному суспільстві як культура більшості, включає в себе такі явища, як засоби масової інформації (телебачення, радіо, інтернет), спорт, кінематограф, музику (у тому числі поп музику), масову літературу, образотворче мистецтво та багато ін. Зміст масової культури обумовлений щоденними подіями,

(C) Швець К., 2014 